\title{
Virtual Learning Environments: use of the cell phone to improve the academic performance of undergraduate engineering students
}

\author{
Tannia Acosta, Mg. ${ }^{1,2}$, Christian Pavón, Mg. ${ }^{2}$, and Gabriela Carrillo, BA $^{2}$ \\ ${ }^{1}$ Agrarian University of Ecuador, Ecuador, tacosta@uagraria.edu.ec \\ 2University of Guayaquil, Ecuador, tannia.acostach@ug.edu.ec, christian.pavonb@ug.edu.ec, gabriela.carrillol@ug.edu.ec
}

\begin{abstract}
The objective of this work is to verify the effectiveness of the use of an application for the cell phone, $M-V L E$ App, which aims to be a support tool for feedback and evaluation of learning. For this, two surveys were designed, one for professors and another for students of an Ecuadorian university, in order to determine the importance and relevance of the research. In this stage, 70 teachers and 54 students participated, then, an experimental study was conducted, in which 30 students participated. They were divided into an experimental group and a control group. The experimental group was allowed to use the $M$ $V L E$ App and the control group was given the traditional class. Two tests were taken: Test 1 and Test 2 . Based on the results of the tests, with $95 \%$ certitude, a value of $p<0.0001$ was obtained in the unpaired test $t$ test, which rejected the null hypothesis and the research hypothesis was accepted. Finally, the use of this type of applications is recommended and it is expected that this work will continue the debate about the use of new information and communication technologies, such as cell phones, within the teaching-learning process.
\end{abstract}

Keywords-- Virtual Learning Environments, Student Evaluation, Educational Apps.

\section{INTRODUCTION}

The new information and communication technologies (NICTs) have been applied in several daily activities of human beings, optimizing resources, which is precisely what this intends to do. Education is one of those important fields in which it has acted with wonderful results, however the use of technological resources has been limited, emphasizing classroom education. [1].

This paper leans its interest to the M-learning (Learning through mobile devices) part of the NICTs, due to the increasing use of mobile devices by the students of all the levels of instruction, among these technological elements the one of greater use by young people, the cell phone.

A study on the impact of mobile technologies in learning [2] mentions that although the use of portable devices to support teaching and learning is a new concept in educational circles today thanks to the web, computer technology has thrived with such dynamism that it is changing the traditional way of obtaining knowledge and applying it within the learning process [3]. Mobile devices (palms, pocket pc, cell phones, etc.) as learning tools will require rethinking by educators, since it is up to them to use them in the most practical way possible [4]. Their closeness to social habits and contemporary life have made, in the case of mobile phones, become a familiar tool in the field of communications [5]. This has caused them to contribute a valuable share in the culture of learning, a kind of educational reengineering that allows greater scope in obtaining knowledge, facilitating even more integration into social and cultural processes.

On the other hand, the evaluation is an essential part of the inter-learning, and it is both a pain for teachers and students, for this reason the research focuses on M-VLE (virtual learning environments through mobile devices) [6]. ], in an attempt to motivate teachers and students to improve the evaluation process with the use of a tool of common use, and of great interest for young people, their mobile phone.

In the first phase a diagnosis of the problem is made in order to understand how the M-VLE work and in what way they contribute to the student's education. In the same way it is specified that the students that learn in a traditional environment are evaluated in the same way. It is also prescribed if students and teachers know about the use of cell phones as a tool for feedback and evaluation.

Based on all the studies carried out, an alternative solution is proposed around the traditional teaching and the limited results of evaluations. The alternative takes the form of a feedback and evaluation application for mobile devices for a Mathematics subject unit of the second semester of the Civil Engineering degree, which aims to overcome low performance factors in this chair, as well as disinterest and apathy for the same.

Research culminated with the creation of the application and it will look like, how to use is also described, as well as steps for installation and use.

Once the application was implemented, we proceeded to evaluate the results obtained with positive consequences of progress in terms of qualifications obtained.

\section{A. Hypothesis}

The research hypothesis is: Students who use M-VLE App perform better than students who do not use it.

The null hypothesis is: Students who use M-VLE App have the same performance as those students who do not use it.

\section{B. M-VLE App}

It is an application for mobile devices that aims, first, to revolutionize the evaluation methods and secondly, to be a tool of support at the level of feedback and evaluation of learning.

Digital Object Identifier (DOI): http://dx.doi.org/10.18687/LACCEI2018.1.1.29 ISBN: 978-0-9993443-1-6

ISSN: $2414-6390$

16 $^{\text {th }}$ LACCEI International Multi-Conference for Engineering, Education, and Technology: "Innovation in Education and Inclusion”, 19-21 July 2018, Lima, United States. 
This will be done through the adequate creation of the assessment instruments, applying reagents that show notably the knowledge acquired, understand how to use the tool properly, and use it in the same way, which will lead to a significant improvement in the academic performance of students.

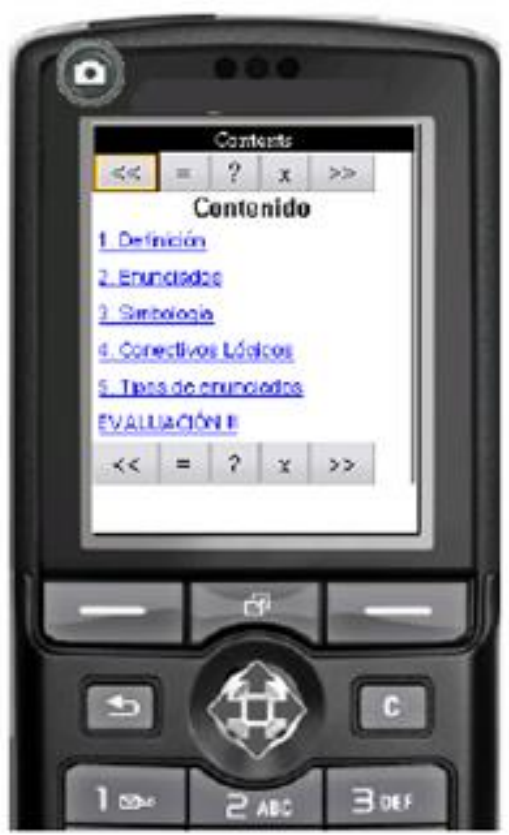

Fig. 1 Main menu of M-VLE App.

The development of evaluative mobile applications should be developed on a unit basis, so that the content does not accumulate and the feedback and evaluation becomes confusing. Likewise, evaluations or only feedbacks can be developed, depending on the needs of students and teachers. However, the evaluations can be done monthly or quarterly, reiterating the importance of curricular planning for teachers. The first version was developed in 2013. The start menu of the application can be seen in Fig. 1. Currently, a version of the application is being developed to be available for IOS and Android.

\section{METHODOLOGY}

A. Focus

For this research, a qualitative analysis was carried out first, since we worked with field research to determine the characteristics of traditional education. In addition, a quantitative analysis was carried out due to the existence of groups of numerical data that were classified and treated mathematically according to the case. The hypotheses were checked by unpaired t test.

B. Mode
The modality of the present investigation was field and applied.Field because it allowed a systematic analysis of problems in real time, with the purpose of describing them; interpreting them, understanding their nature and constituent factors, explaining their causes and effects or predicting their occurrences. This will be done through the use of methods characteristic of any of the paradigms or Research approaches known or in development, which will also be given in the place of the facts.

Applied because it had as starting point the contents of Mathematical Logic, to go through the principles, elements of design, and laws of Gestalt, combining all this to statements related to the design, arriving at a feedback and evaluation of the knowledge acquired by the students through the new information and communication technologies, specifically the M-VLE.

\section{Research subjects}

The research subjects were 70 teachers and 54 students belonging to an Ecuadorian university that offers technical careers, to which a survey was applied. In addition, 30 students participated in the second semester of a mathematics course at an Ecuadorian university.

\section{Procedure}

The information was collected through bibliographic records and web pages, after which surveys were applied to determine the importance of the research, later the research group was divided and surveys were carried out to those who applied the project and to who weren't, to determine the success of the investigation. The data and information obtained in the field research phase were processed, using all the statistical techniques that are feasible to apply for the case of the present investigation, following certain procedures:

- Critical review of the information collected, that is, clearing defective information, contradictory, incomplete or not pertinent.

- Repeat collection in certain individual cases to correct a response failure.

- Tabulation according to variables.

- Statistical study of data for the presentation of results.

\section{RESULTS}

A. Results from the surveys

In order to determine the importance of the research, surveys were applied to teachers and students of the university.

The results of the survey directed to teachers are presented in Fig. 2, which contained the following questions:

- Question 1: Do you know what M-VLE is?

- Question 2: Have you ever used M-VLE in your educational activities? 
- Question 3: Besides the computer, do you consider that other technological devices should be used to improve learning?

- Question 4: Do you think that evaluation methods should be innovated?

- Question 5: Do you think that cell phones could be a learning tool for the student?



Fig. 2 Results of the survey for teachers.

In the first two questions, it can be seen that teachers do not know about M-VLA, so a prior training should be carried out before putting it into practice. Questions 3 and 4 show the interest of teachers in applying new communication and information technologies in their teaching-learning processes. However, in question 5, teachers do not believe that the cell phone can be a device that can be used as a tool during their classes. This is because most people think that the telephone is a distraction [7] or it encourages students to use misinformation during evaluations. The results of the survey directed to students are presented in Fig. 3, which contained the following questions:

- Question 1: Do you have a cell phone?

- Question 2: Do you have a smartphone?

- Question 3: Do you use the cell phone more often than the computer?

- Question 4: Do you keep your cell phone turned on for most of the day?

- Question 5: Do you know the M-VLEs?

- Question 6: Do you think that evaluation methods should be changed in Propositional Logic?

- Question 7: Have you used your cell phone for academic purposes?

- Question 8: Do you think your academic performance would improve if traditional assessment instruments were changed?

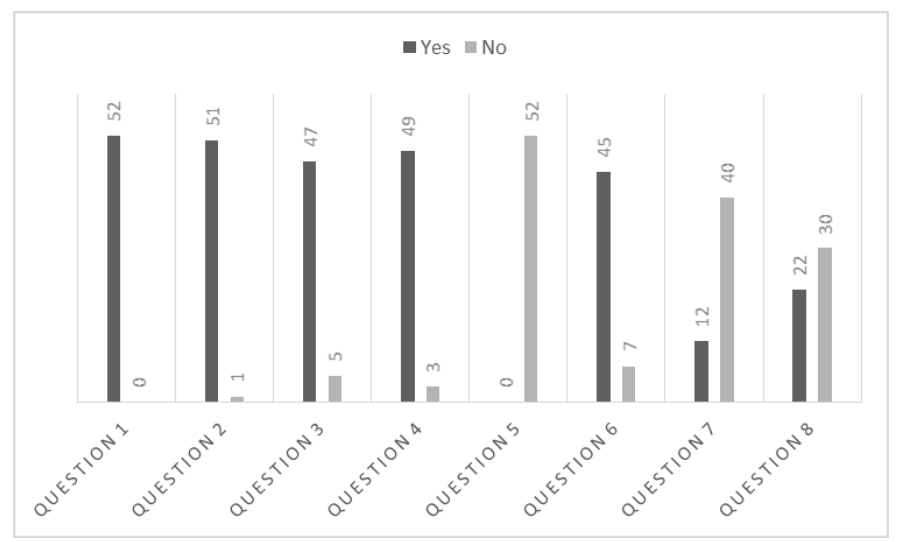

Fig. 3 Results of the survey for students.

In the first two questions you can see that students have a cell phone and most of them a Smartphone, which favored the use of M-VLE App. However, in question 5 it can be seen that no student knows the application. This is not an important limitation since students are currently familiar with the use of new applications in the cell phone. Finally, it can be seen in the last two questions that students do not use cell phones frequently for academic purposes and that, like their teachers, they do not see cell phones as a tool for the teaching-learning process.

\section{B. Results of the hypothesis test}

Below is shown in Fig. 4 the results obtained in the experimental group and the control group, which differ in the use of M-VLE App. There were two evaluation sessions, Test 1 and Test 2.

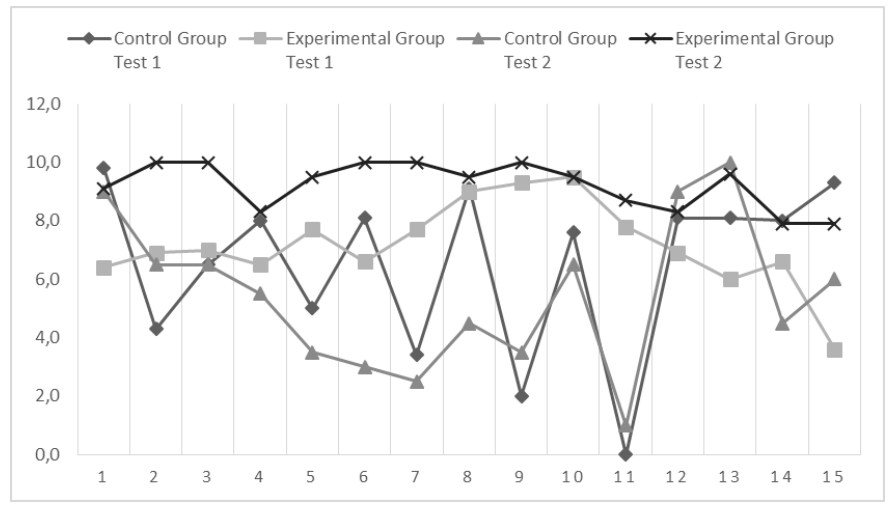

Fig. 4 Results of the control group and the experimental group.

Based on these results, the unpaired t test was applied to the data. The results of this test are shown below: 
TABLE I

RESULTS OF UNPAIRED T TEST

\begin{tabular}{|c|c|c|}
\hline & \\
\hline & Test 1 & Test 2 \\
\hline Data review: & \begin{tabular}{lcc} 
& CG & EG \\
Mean & 6.487 & 7.167 \\
SD & 2.904 & 1.470 \\
SEM & 0.750 & 0.380 \\
$\mathrm{~N}$ & 15 & 15 \\
& \multicolumn{3}{l}{} \\
CG: Control group \\
EG: Experimental group
\end{tabular} & 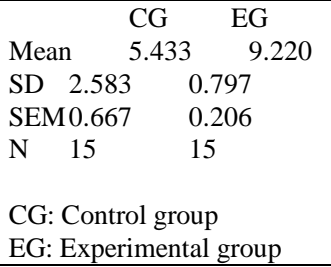 \\
\hline $\begin{array}{l}\text { Intermediate } \\
\text { values used in } \\
\text { calculations: }\end{array}$ & $\begin{array}{l}\mathrm{t}=0.8091 \\
\mathrm{df}=28 \\
\text { standard error of difference } \\
=0.840\end{array}$ & $\begin{array}{l}\mathrm{t}=5.4249 \\
\mathrm{df}=28 \\
\text { standard error of difference } \\
=0.698\end{array}$ \\
\hline $\begin{array}{l}\text { Confidence } \\
\text { interval: }\end{array}$ & $\begin{array}{l}\text { The mean of Group One } \\
\text { minus Group Two equals - } \\
0.680 \\
95 \% \text { confidence interval of } \\
\text { this difference: From - } \\
2.402 \text { to } 1.042\end{array}$ & $\begin{array}{l}\text { The mean of Group One } \\
\text { minus Group Two equals - } \\
3.787 \\
95 \% \text { confidence interval of } \\
\text { this difference: From }-5.216 \\
\text { to }-2.357\end{array}$ \\
\hline $\begin{array}{l}P \text { value and } \\
\text { statistical } \\
\text { significance: }\end{array}$ & $\begin{array}{l}\text { The two-tailed P value } \\
\text { equals } 0.4253 \\
\text { By conventional criteria, } \\
\text { this difference is } \\
\text { considered to be not } \\
\text { statistically significant. }\end{array}$ & $\begin{array}{l}\text { The two-tailed } \mathrm{P} \text { value is } \\
\text { less than } 0.0001 \\
\text { By conventional criteria, } \\
\text { this difference is considered } \\
\text { to be extremely statistically } \\
\text { significant. }\end{array}$ \\
\hline
\end{tabular}

As can be seen in Table I, Test 1 does not present statistically significant differences between the two working groups. This is because it takes time for students to become familiar with the use of the application.

After the course of a week of use, the results of Test 2 were obtained, in which an extremely significant difference is observed, with which the null hypothesis is rejected and the research hypothesis is accepted.

\section{CONCLUSIONS}

It is necessary that new information and communication technologies be integrated not only as a tool, but also as an active part of all teaching processes, including evaluation, to be able to migrate from traditional approaches [8].

Based on the results of the study, the hypothesis was verified that students who use M-VLE App achieve better results in the evaluations than those who do not use it. This provides direct empirical evidence of the importance of the use of new information and communication technologies in the learning of undergraduate students.

These results can be attributed to the fact that the use of new information and communication technologies allow education to be transformed in a positive manner for all those who have an active part in the teaching-learning process [9]. The learning outcomes of this study are complemented by work [10] [11] [12] [13] in which students use applications similar to M-VLE App.

In addition, the elaboration of the questionnaires takes less time to the teacher as experience is gained and a database with the reagents is fed, for which, in the short term the use of this type of evaluations saves environmental and time resources for the teachers who use them.

Finally, apps like M-VLE are applicable to all fields of knowledge, so its use is recommended and it is expected that this work will continue the debate about the use of new information and communication technologies, such as the cell phone [14] within the teaching-learning process.

\section{REFERENCES}

[1] S. Chowdhry, K. Sieler y L. Alwis, «A Study of the Impact of Technology-Enhanced Learning on Student Academic Performance,» Journal of Perspectives in Applied Academic Practice, vol. 2, n $\mathrm{n}^{\circ} 3$, pp. 315, 2014.

[2] J. Saez, «Valoración del impacto que tienen las TIC en educación primaria en los procesos de aprendizaje y en los resultados a través de una triangulación de datos,» Revista Latinoamericana de Tecnología Educativa, vol. 11, no 2, pp. 11-24, 2012.

[3] S. Ghavifekr y W. A. Wan Rosdy, «Teaching and Learning with Technology: Effectiveness of ICT Integration in Schools,» International Journal of Research in Education and Science, vol. 1, $\mathrm{n}^{\circ}$ 2, pp. 175-191, 2015.

[4] K. Vajargah, S. Jahani y N. Azadmanesh, «Application of ICTs in teaching and learning at university level: the case of Shahid Beheshti University,» The Turkish Online Journal of Educational Technology, vol. 9, no 2, pp. 33-39, 2010.

[5] A. Basantes, M. Naranjo, M. Gallegos y N. Benítez, «Los Dispositivos Móviles en el Proceso de Aprendizaje de la Facultad de Educación Ciencia y Tecnología de la Universidad Técnica del Norte de Ecuador,» Formación Universitaria, vol. 10, $\mathrm{n}^{\circ}$ 2, pp. 79-88, 2017.

[6] C. Pavón, J. Encalada, K. Matute y J. Rodríguez, «Web page to improve feedback in the teaching of Physics in baccalaureate: partial results of a research seed project,» de 15th LACCEI International Multi-Conference for Engineering, Education, and Technology: "Global Partnerships for Development and Engineering Education”, Boca Raton, 2017.

[7] H. Oliva, «El uso de teléfonos móviles en el sistema educativo público de El Salvador: ¿Recurso didáctico o distractor pedagógico?,» Realidad y Reflexión, vol. 14, nº 40, pp. 58-76, 2014.

[8] P. Hermosa, «Influencia de las tecnologías de información y comunicación (TIC) en el proceso enseñanza-aprendizaje: una mejora de las competencias digitales,» Revista Científica General José María Córdova, vol. 13, nº 16, pp. 121-132, 2015.

[9] M. Mendoza, «El teléfono celular como mediador en el proceso de enseñanza-aprendizaje,» Revista Omnia, vol. 20, n 3, pp. 9-22, 2014.

[10] J. Silva, «Un modelo pedagógico virtual centrado en las E-actividades,» RED. Revista de Educación a Distancia, $\mathrm{n}^{\circ}$ 53, 2017.

[11] S. Suárez, C. Carreto y E. Ruiz, «Modelo de administración del conocimiento aplicado a enseñanza-aprendizaje por medio de dispositivos móviles,» Innovación Educativa, vol. 12, n 58, pp. 151-165, 2012.

[12] J. Tessier, «Student Impressions of Academic Cell Phone Use in the Classroom,» Journal of College Science Teaching, vol. 43, n 1, pp. 2529, 2013.

[13] F. Díaz, «Educación y nuevas tecnologías de la información: ¿Hacia un paradigma educativo innovador?,» Revista Electrónica Sinéctica, $\mathrm{n}^{\circ} 30$, pp. 1-15, 2008.

[14] J. Correa y J. de Pablos, «Nuevas tecnologías e innovación educativa,» Revista de Psicodidáctica, vol. 14, nº 1, pp. 133-145, 2009.

16 $^{\text {th }}$ LACCEI International Multi-Conference for Engineering, Education, and Technology: "Innovation in Education and Inclusion", 19-21 July 2018, Lima, United States. 